DISCHARGE RATINGS FOR TAINTER AND ROLLER GATES

AT LOCK AND DAM NO. 25 ON THE MISSISSIPPI RIVER

NEAR WINFIELD, MISSOURI

By Terry W. Alexander

U.S. GEOLOGICAL SURVEY

Water-Resources Investigations Report 92-4118

Prepared in cooperation with the

U.S. ARMY CORPS OF ENGINEERS,

ST. LOUIS DISTRICT

Rolla, Missouri 


\section{U.S. DEPARTMENT OF THE INTERIOR}

MANUEL LUJAN, JR., Secretary

U.S. GEOLOGICAL SURVEY

Dallas L. Peck, Director

For additional information write to:

District Chief

U.S. Geological Survey

1400 Independence Road

Mail Stop 200

Rolla, Missouri 65401
Copies of this report can be purchased from:

U.S. Geological Survey

Books and Open-File Reports Section Federal Center

Box 25425

Denver, Colorado 80225 


\section{CONTENTS}

Page

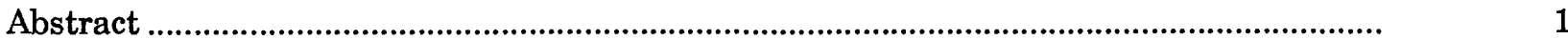

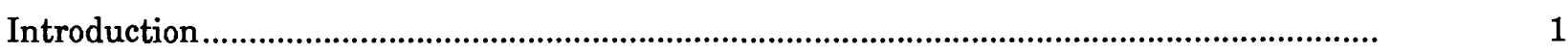

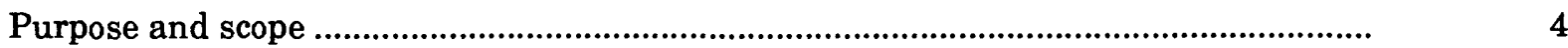

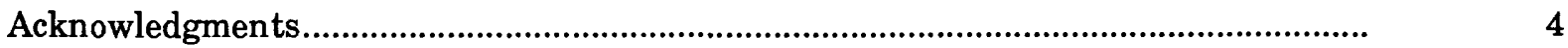

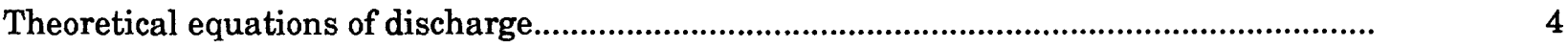

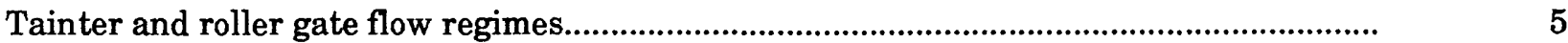

Measurements of hydraulic-control variables and discharges ......................................

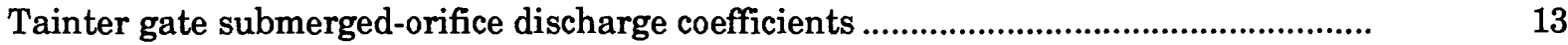

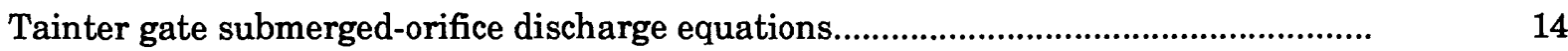

Roller gate submerged-orifice discharge coefficients...............................................

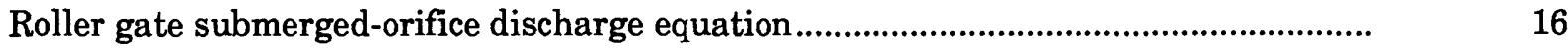

Discharge ratings for tainter and roller gates......................................................... 16

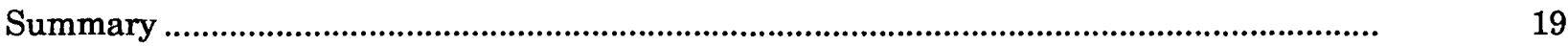

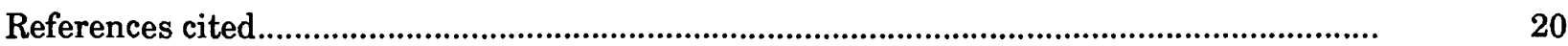




\section{ILLUSTRATIONS}

Page

Figure 1. Map showing location of Lock and Dam No. 25 on the Mississippi River

2-5. Diagrams showing:

2. Locations of flow controls at Lock and Dam No. 25...................................

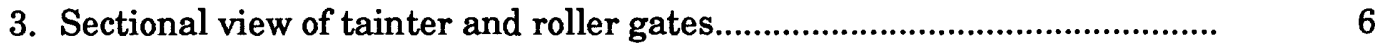

4. Velocity observations of October 19-20, 1988, for a 2 -foot gate opening at tainter gates $3,7,15$, and roller gate 11 .

5. Velocity observations of July 14,1990 , for a 14 -foot gate opening at tainter gates $3,7,15$, and roller gate 11

6. Graph showing relation between submerged-orifice discharge coefficients and orifice-submergence ratios for tainter gates

7. Graph showing relation between submerged-orifice discharge coefficients and orifice-submergence ratios for roller gates.

\section{TABLES}

Table 1. Theoretical equations of discharge for flow controlled by a tainter or roller gate

2. Summary of hydraulic-control variables and current-meter discharge measurements

3. Summary of theoretical discharge equations for submerged-orifice flow under a single tainter or roller gate

4. Discharge rating table for a tainter gate with submerged-orifice flow for normal headwater and tailwater elevations

5. Discharge rating table for a roller gate with submerged-orifice flow for normal headwater and tailwater elevations 


\section{CONVERSION FACTORS AND VERTICAL DATUM}

\section{Multiply}

foot (ft)

mile (mi)

foot per second (ft/s)

foot per second squared $\left(\mathrm{ft} / \mathrm{s}^{2}\right)$

cubic foot per second $\left(\mathrm{ft}^{3} / \mathrm{s}\right)$

pound, avoirdupois (lb)
By

0.3048

1.609

0.3048

0.3048

0.02832

0.4536

\section{To Obtain}

meter

kilometer

meter per second

meter per second squared

cubic meter per second

kilogram

Sea level: In this report, "sea level" refers to the National Geodetic Vertical Datum of 1929--a geodetic datum derived from a general adjustment of the first-order level nets of the United States and Canada, formerly called Sea Level Datum of 1929.

Note: The non-dimensionless constants used in some of the equations can be used only with inchpound units. 


\section{SYMBOLS AND UNITS}

Symbol

B

C

$\mathrm{C}_{\mathrm{gs}}$

$\mathrm{C}_{\mathrm{w}}$

$\mathrm{C}_{\mathrm{ws}}$

g

$\mathrm{h}_{\mathrm{g}}$

$\mathrm{h}_{1}$

$\mathrm{h}_{3}$

Q

$\mathrm{q}_{\mathrm{GL}}$

$\Delta \mathrm{h}$
Definition

Width of tainter or roller gate

Free-orifice flow coefficient of discharge

Submerged-orifice flow coefficient of discharge

Free-weir flow coefficient of discharge

Submerged-weir flow coefficient of discharge

Acceleration due to gravity $\left(32.15 \mathrm{ft} / \mathrm{s}^{2}\right)$

Vertical height of tainter or roller gate opening

Static-headwater depth above gate sill

Static-tailwater depth above gate sill

Discharge

Leakage discharge per gate

Static head differential $\left(h_{1}-h_{3}\right)$ $\mathrm{ft} / \mathrm{s}^{2}$

Unit

$\mathrm{ft}$

$\mathrm{ft}$

$\mathrm{ft}$

$\mathrm{ft}$

$\mathrm{ft}^{3} / \mathrm{s}$

$\mathrm{ft}^{3} / \mathrm{s}$

$\mathrm{ft}$ 


\title{
DISCHARGE RATINGS FOR TAINTER AND ROLLER GATES AT LOCK AND DAM NO. 25 ON THE MISSISSIPPI RIVER NEAR WINFIELD, MISSOURI
}

\author{
By \\ Terry W. Alexander
}

\begin{abstract}
The water-surface elevations on the Inland Waterway Navigation System of the upper Mississippi River are controlled during normal operating conditions by various flow controls located at 29 locks and dams. The headwater (navigation pool) and tailwater elevations at Lock and Dam No. 25 near Winfield, Missouri, are controlled by the regulation of 14 tainter gates and 3 roller gates. Stage-discharge ratings for these tainter and roller gates were developed for use in computing discharge through Dam No. 25 and to aid in regulating the navigation pool within its normal operating limits of $\mathbf{4 2 9 . 7 0}$ to $\mathbf{4 3 4 . 0 0}$ feet. Hydraulic-control variables and discharges were measured at several of the tainter and roller gates and analyzed for this report.
\end{abstract}

A total of 57 measurements of discharge that ranged from 370 to 9,220 cubic feet per second were made in the tainter and roller gate forebays. The measured discharges were used to define flow regimes as a function of static-headwater depth $\left(h_{1}\right)$, static-tailwater depth $\left(h_{3}\right)$, and vertical height of tainter or roller gate opening $\left(\mathrm{h}_{\mathrm{g}}\right)$. Submerged-orifice flow is the predominant flow regime at Lock and Dam No. 25.

Thirty-seven discharge measurements defining coefficients of discharge $\left(\mathrm{C}_{\mathrm{gs}}\right)$ ranging from 0.087 $\left(\mathrm{h}_{\mathrm{g}}=1 \mathrm{foot}\right)$ to $0.731\left(\mathrm{~h}_{\mathrm{g}}=14\right.$ feet) were used to develop the submerged-orifice discharge coefficient relation for the tainter gates. Seventeen discharge measurements defining coefficients of discharge ranging from $0.038\left(h_{g}=1\right.$ foot $)$ to $0.534\left(h_{g}=14\right.$ feet) were used to develop the submerged-orifice discharge coefficient relation for the roller gates. Also, three discharge measurements were made with the gates closed $\left(h_{g}=0\right)$ to evaluate the tainter and roller gate leakage discharge relations. Theoretical equations that express discharge per gate $(Q)$ as a function of discrete hydraulic-control variables were developed from these discharge coefficient and gate leakage discharge relations. The resulting equations of discharge are applicable to gate openings of 1 foot to 14 feet and for orifice-submergence ratios $\left(h_{3} / h_{g}\right)$ ranging from 1.4 to 11.0 ; thus, these equations can be used to compute discharges for regulated flow conditions not otherwise defined by the current-meter discharge measurements. Discharge rating tables for the tainter and roller gates are given for selected combinations of headwater and tailwater elevations.

\section{INTRODUCTION}

The Inland Waterway Navigation System for the upper Mississippi River basin was authorized by Congress in July 1930 with passage of the River and Harbor Act. This act provided for the construction of a series of lock and dam flow-regulating structures to maintain a 9-ft deep and 400-ft wide navigation channel from Minneapolis, Minnesota, to St. Louis, Missouri. The efficient operation of the Inland Waterway Navigation System requires reliable stage-discharge relations for all flow controls within the system.

Lock and Dam No. 25 at river mi 241.4 near Winfield, Missouri (fig. 1), is 1 of 29 lock and dam flow-regulating structures in the upper Mississippi River basin that are maintained and operated by the U.S. Army Corps of Engineers. Dam No. 25 is 4,078 ft long (fig. 2) and consists of 1,296 ft of tainter and roller gates, $216 \mathrm{ft}$ of storage yard (non-overflow earth dike), and $2,566 \mathrm{ft}$ of overflow earth dike. 

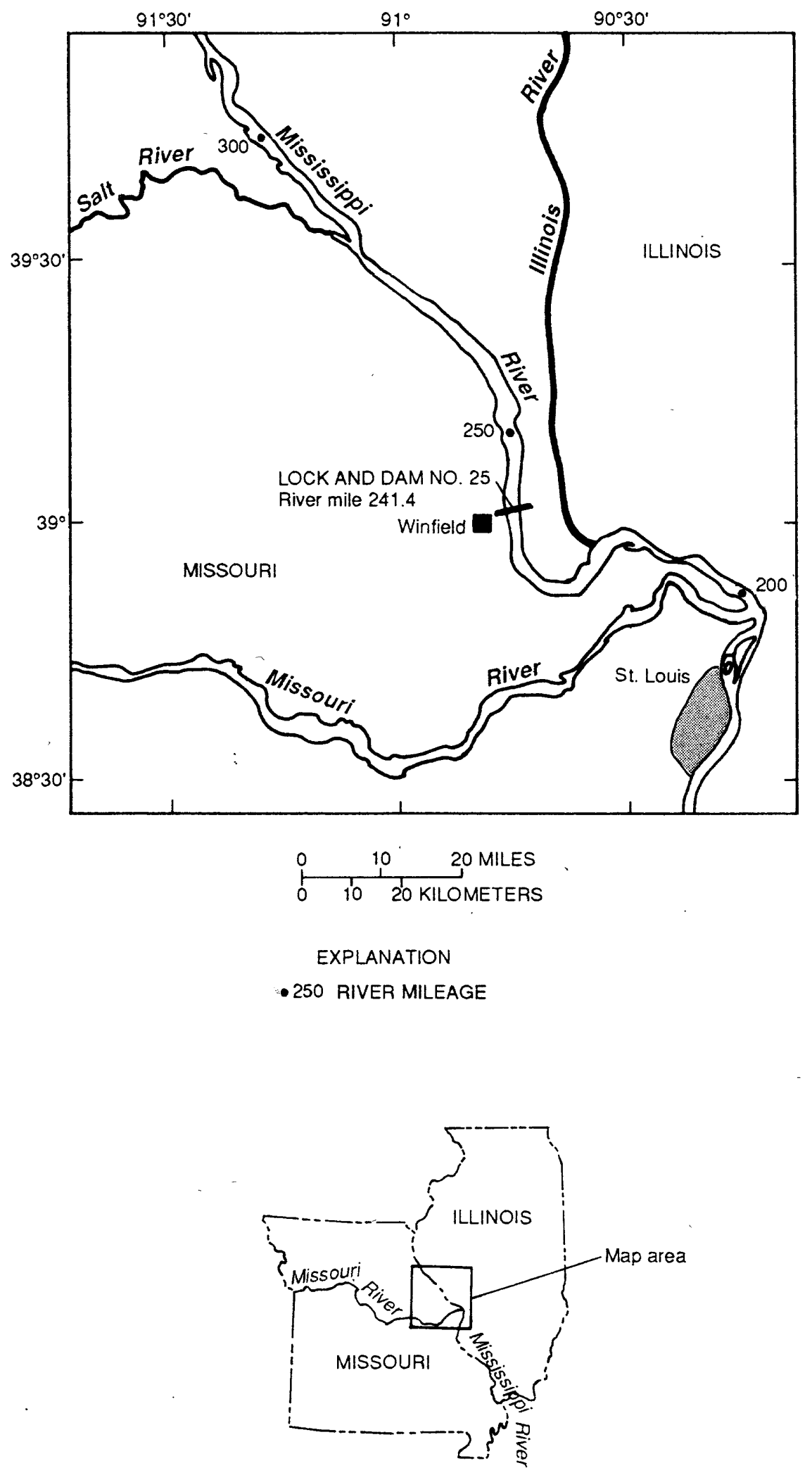

Figure 1.--Location of Lock and Dam No. 25 on the Mississippi River. 


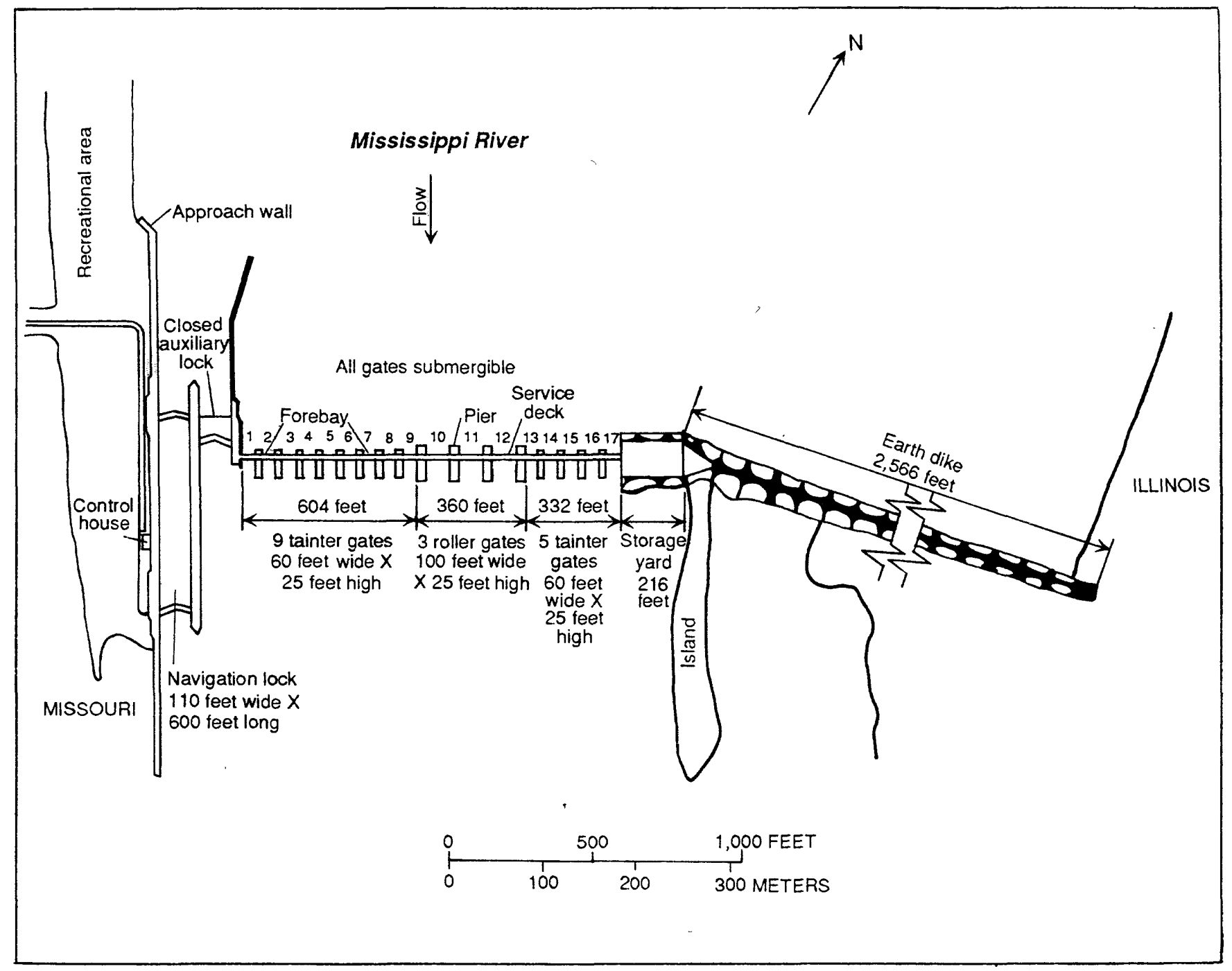

EXPLANATION

1 TAINTER OR ROLLER GATE NUMBER

Figure 2.--Locations of flow controls at Lock and Dam No. 25 (modified from U.S. Army Corps of Engineers, 1990). 
Nine of the tainter gates, which are located adjacent to the lock, are separated from the five remaining tainter gates by three roller gates. The roller gates are positioned near the middle of the Mississippi River main channel. The navigation lock is $110 \mathrm{ft}$ wide by $600 \mathrm{ft}$ long.

The principal responsibilities of water-control management are assigned to the St. Louis District office of the U.S. Army Corps of Engineers, Potamology Section of the Hydrologic and Hydraulics Branch, Engineering Division. Lock and Dam No. 25, a run-of-the-river dam, cannot be used for flood-control purposes. Various combinations of tainter and roller gate openings currently (1992) are used to maintain the headwater (navigation pool) elevation within the normal operating limits of 429.70 and $434.00 \mathrm{ft}$ (S.K. Ellis, U.S. Army Corps of Engineers, oral commun., 1990).

Because the water-surface slope between flow-regulating structures can approach zero during periods of low flow, the traditional methods that require slope to calculate discharge are not satisfactory at Lock and Dam No. 25. Therefore, a cooperative effort between the U.S. Geological Survey and the U.S. Army Corps of Engineers, St. Louis District, was begun in 1988 to develop stage-discharge relations for the 14 tainter and 3 roller gate flow controls at this structure.

\section{Purpose and Scope}

The purpose of this report is to present discharge ratings for the tainter and roller gate flow controls at Lock and Dam No. 25. Stage-discharge relations (equations of discharge) were developed by using results of current-meter discharge measurements made in the forebays of selected tainter and roller gates. These discharge measurements were used to develop discharge coefficient relations for hydraulic-control conditions that may occur during normal operating periods. The equations of discharge can be used to compute discharge rating tables for most combinations of headwater and tailwater elevations and vertical height of tainter or roller gate openings, including water-surface elevations and gate openings not represented by the discharge measurements made during this study.

This study was limited to the analysis of submerged-orifice flow regime under the tainter and roller gate flow controls. No attempts were made to define or develop discharge ratings for flow through the navigation lock, possible flow over the earth dike, or open-river flow when all gates are out of the water.

\section{Acknowledgments}

A special thanks to Lockmasters Fred I. Troutner, Jr. and Stevenson K. Ellis, who were helpful in arranging the tainter and roller gate openings for discharge measurements and for providing a crane operator when needed.

\section{THEORETICAL EQUATIONS OF DISCHARGE}

Four types of flow-control structures are present at Lock and Dam No. 25: tainter gates, roller gates, a navigation lock, and an earth dike (fig. 2). The 14 tainter gates and 3 roller gates are the only flow controls for which hydraulic theory is used to develop a method for computing reliable stage-discharge relations (equations of discharge).

Collins (1977, p. 2-3) and Stuthmann and Sanders (1982, p. A-36 to A-40) summarize the hydraulic-control conditions that define flow regimes possible at multipurpose flow-regulating structures and present their corresponding theoretical equations of discharge. The hydraulic theory used to develop these theoretical equations assumes steady, uniform flow. This theory requires that the energy and continuity equations are balanced between an approach section and a section just downstream from the control structure. Possible flow regimes, necessary hydraulic-control conditions, and the theoretical equations of discharge for flow controlled by a tainter or roller gate are summarized in table 1. 
Table 1.--Theoretical equations of discharge for flow controlled by a tainter or roller gate (modified from Collins, 1977)

$\left[h_{g}\right.$, vertical height of tainter or roller gate opening; <, less than; $h_{1}$, static-headwater depth; $h_{3}$, static-tailwater depth; $Q$, discharge; $C$, free-orifice flow coefficient of discharge; $B$, tainter or roller gate width; $g$, acceleration due to gravity; $\geq$, greater than or equal to; $\mathrm{C}_{\mathrm{gg}}$, submerged-orifice flow coefficient of discharge;

$\Delta h$, static head differential $\left(h_{1}-h_{3}\right) ;>$, greater than; $C_{w}$ free-weir flow coefficient of discharge; $\mathrm{C}_{\mathrm{ws}}$, submerged-weir flow coefficient of discharge]

\begin{tabular}{|c|c|c|c|}
\hline Flow regime & $\begin{array}{l}\text { Hydraulic-control } \\
\text { conditions }\end{array}$ & Equation of discharge & $\begin{array}{l}\text { Equation } \\
\text { number }\end{array}$ \\
\hline $\begin{array}{l}\text { Free-orifice } \\
\text { Submerged-orifice }\end{array}$ & $\begin{array}{l}h_{g}<0.67 h_{1} \text { and } h_{3}<h_{g} \\
h_{g}<0.67 h_{1} \text { and } h_{3} \geq h_{g}\end{array}$ & $\begin{array}{l}\mathrm{Q}=\mathrm{C}\left[\mathrm{h}_{\mathrm{g}} \mathrm{B}\left(2 \mathrm{gh} \mathrm{h}_{1}\right)^{0.5}\right] \\
\mathrm{Q}=\mathrm{C}_{\mathrm{gg}}\left[\mathrm{h}_{3} \mathrm{~B}(2 \mathrm{~g} \Delta \mathrm{h})^{0.5}\right]\end{array}$ & $\begin{array}{l}1 \\
2\end{array}$ \\
\hline $\begin{array}{l}\text { Free-weir } \\
\text { Submerged-weir }\end{array}$ & $\begin{array}{l}\text { or }{ }^{a} h_{g}>0.67 h_{1} \text { and } h_{3}>h_{g} \\
h_{g} \geq 0.67 h_{1} \text { and } h_{3} / h_{1}<0.6 \\
h_{g} \geq 0.67 h_{1}, h_{3} / h_{1} \geq 0.6, \\
\text { and }{ }^{a} h_{3}<h_{g}\end{array}$ & $\begin{array}{l}Q=C_{w}\left[B h_{1}^{1.5}\right] \\
Q=C_{w} C_{w_{s}}\left[B h_{1}^{1.5}\right]\end{array}$ & $\begin{array}{l}3 \\
4\end{array}$ \\
\hline
\end{tabular}

a Stuthmann and Sanders (1982, p. A-37).

The bracketed parts of these four equations represent theoretical expressions of discharge for a tainter or roller gate $B$ units in width. The independent hydraulic-control variables are static-headwater depth $\left(h_{1}\right)$, static-tailwater depth $\left(h_{3}\right)$, and vertical height of tainter or roller gate opening $\left(h_{g}\right)$. The static depths $\left(h_{1}\right.$ and $\left.h_{3}\right)$ are the vertical distances between the headwater and tailwater elevations and the sill (fig. 3). The coefficients of discharge $\left(\mathrm{C}, \mathrm{C}_{\mathrm{gg}}, \mathrm{C}_{\mathrm{w}}\right.$, and $\left.\mathrm{C}_{\mathrm{ws}}\right)$ are unknown, but can be determined through a calibration process. These coefficients are defined by the ratio of measured discharge to theoretical discharge; therefore, a coefficient of discharge can be calculated from each current-meter measurement of discharge if all other hydraulic-control variables are known or fixed.

\section{TAINTER AND ROLLER GATE FLOW REGIMES}

The vertical height of gate opening, $h_{g}$, is the most important hydraulic-control variable used in determining both tainter and roller gate flow regimes. The hydraulic-control condition that separates orifice and weir flow regimes is based on a critical depth analysis of flow in a rectangular section. If the gate opening $\left(h_{g}\right)$ is less than the computed critical depth $\left(0.67 h_{1}\right)$, then orifice flow occurs under the gate. If the gate opening equals or exceeds the computed critical depth, the gate opening has no effect on the discharge; thus, weir flow results with the concrete gate sill functioning as a broad-crested weir (Collins, 1977, p. 4). Stuthmann and Sanders (1982, p. A-37), however, provide alternative hydraulic-control conditions for distinguishing the orifice flow regime from the weir flow regime. For this study, hydraulic-control conditions defining the tainter and roller gate flow regimes at Lock and Dam No. 25 are listed in table 1.

Dam No. 25 is never operated within the free-orifice flow regime. Because of the difficulties involved in raising the tainter and roller gates (which can be submerged $8 \mathrm{ft}$ ) from a submerged position, both gate types are submerged (free-weir flow) only periodically for flushing ice or other debris (S.K. Ellis, oral commun., 1991). The submerged-weir flow regime may occur infrequently for periods of 24 hours or less, usually just before or just after open-river conditions $\left(h_{g}>14\right)$. Consequently, the free-orifice, free-weir, and submerged-weir flow regimes are of negligible importance and are not evaluated in this study. The predominant tainter and roller gate flow regime is submerged-orifice flow. 


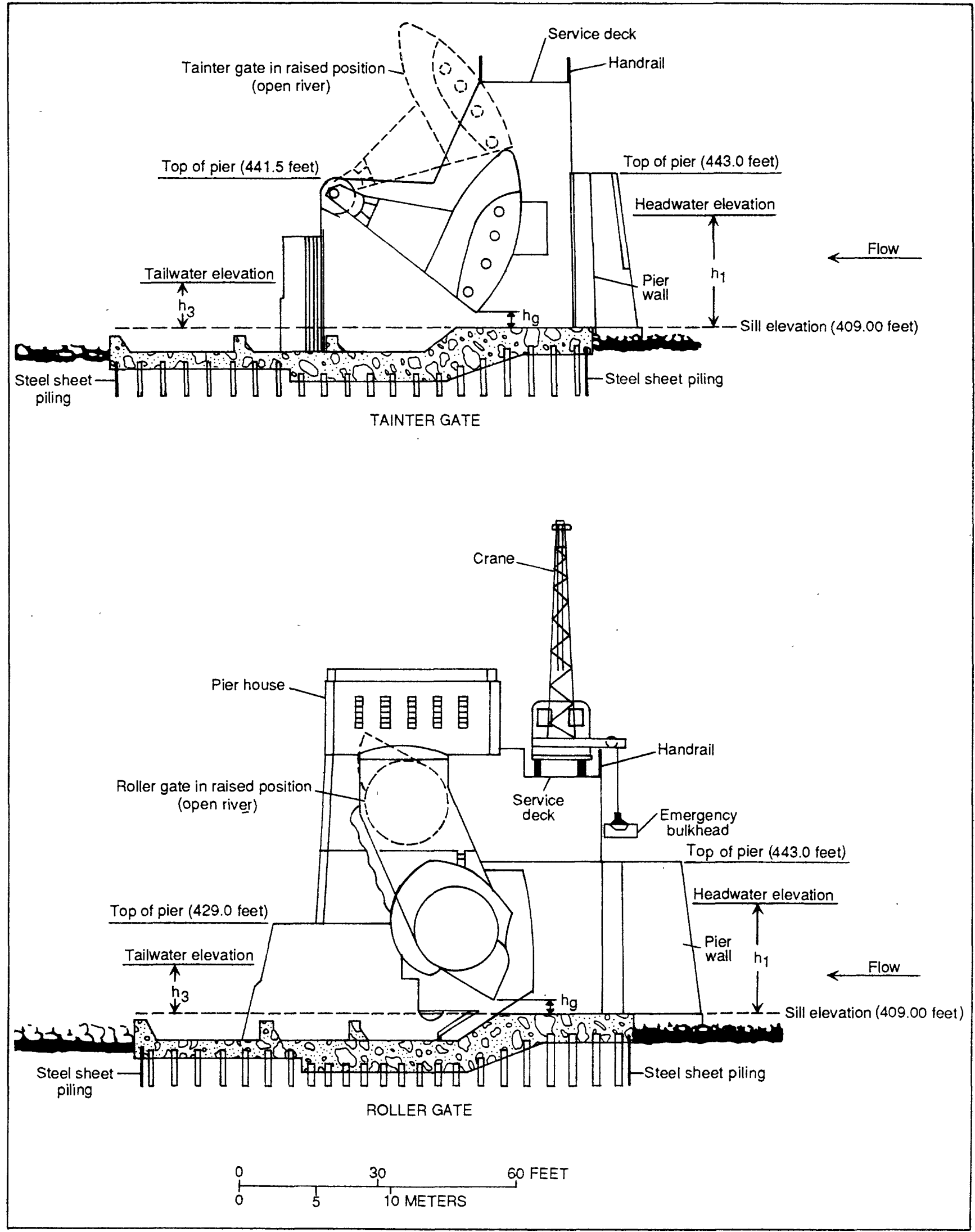

Figure 3.--Sectional view of tainter and roller gates (modified from U.S. Army Corps of Engineers, 1980). 
In this report, stage-discharge relations are presented for the submerged-orifice flow regime. At least 1 current-meter discharge measurement was made at 10 of the 17 gates during submerged-orifice hydraulic-control conditions, while discharges under gates $3,7,11$, and 15 were measured throughout the normal range of tainter or roller gate openings $\left(1 \leq h_{g} \leq 14\right)$.

\section{MEASUREMENTS OF HYDRAULIC-CONTROL VARIABLES AND DISCHARGES}

The 14 tainter gates operate between pier walls with a 60 -ft opening and are $25 \mathrm{ft}$ high; however, the 3 roller gates operate between pier walls with a $100-\mathrm{ft}$ opening and also are $25 \mathrm{ft}$ high. The tainter and roller gates are built under a service deck, and the service deck also provides access to each gate from a moveable crane. Thus, both the deck and crane (fig. 3) provide access to individual forebays, allowing for use of standard U.S. Geological Survey current-meter measuring equipment.

Stage-discharge relations for all flow regimes can be developed from measurements of hydraulic-control variables and discharges at a single tainter or roller gate if all gates are of the same design (Collins, 1977, p. 4); however, in an attempt to average variations in both the tainter and roller gate entrance and exit losses, 54 current-meter discharge measurements were made in the forebays of 7 tainter and 3 roller gates during submerged-orifice flow conditions $\left(0<h_{g} \leq 14\right)$. Three discharge measurements were made with gates closed $\left(h_{g}=0\right)$ to evaluate the tainter and roller gate leakage discharge resulting from the lower gate seals being worn or dented and not forming a tight fit against the concrete sill. These 57 measurements of hydraulic-control variables and discharges that were used to develop the stage-discharge relations are listed in table 2.

Discharge measurements for tainter and roller gate openings of $4 \mathrm{ft}$ or less $\left(\mathrm{h}_{\mathrm{g}} \leq 4\right)$ were made along the upstream handrail of the service deck, whereas discharge measurements for gate openings greater than $4 \mathrm{ft}\left(\mathrm{h}_{\mathrm{g}}>4\right)$ were made from the movable crane (emergency bulkhead) to prevent the measuring equipment from drifting downstream into the gate opening (orifice section). During these discharge measurements, velocity observations in each vertical at 0.2 and 0.8 of the static-headwater depth (two-point method) were obtained by using a Price-type AA current meter suspended with a Columbus sounding weight (100 or $150 \mathrm{lbs}$ ) from a collapsible bridge boom. To verify that the two-point method was acceptable for determining the mean velocity in each vertical (Rantz and others, 1982, $p$. 132-134), a set of velocity observations (one vertical) was made using the vertical-velocity curve method (0.1-depth increments between 0.1 and 0.9 of the static-headwater depth). Mean velocities determined by using the two-point method were within 2 percent (on average) of those determined from the vertical-velocity curve method (figs. 4 and 5). Thus, the standard two-point method for determining mean velocities was used in this study.

To minimize fluctuations in headwater and tailwater elevations, all tainter and roller gate openings were held constant during each discharge measurement to most accurately simulate steady-flow conditions. All gate openings were set by U.S. Army Corps of Engineers personnel. The tainter gate openings were set from the service deck by referencing the gate-indicator gages located on the downstream pier walls, whereas the roller gates were set by using a position-indicator gage located inside the roller gate pier house. The 17 gates at Lock and Dam No. 25 are of the submergible type, and accurate calculation of a true tainter or roller gate opening is impossible. Therefore, corrections to the gate- and position-indicator gages are unobtainable and were assumed to be correct within plus or minus $0.1 \mathrm{ft}$. Gate leakage $\left(\mathrm{h}_{\mathrm{g}}=0\right)$ is common to submergible tainter or roller gates because of the clearance needed between the gate and sill. In this study, the leakage discharge per gate $\left(\mathrm{q}_{\mathrm{GL}}\right)$ was not separated from the current-meter discharge measurements. The headwater and tailwater elevations were monitored from U.S. Army Corps of Engineers continuous recording gages located in the control house. The static-headwater and static-tailwater depths, $h_{1}$ and $h_{3}$, are referenced from the tainter and roller gate concrete sill elevation of $409.00 \mathrm{ft}$. 


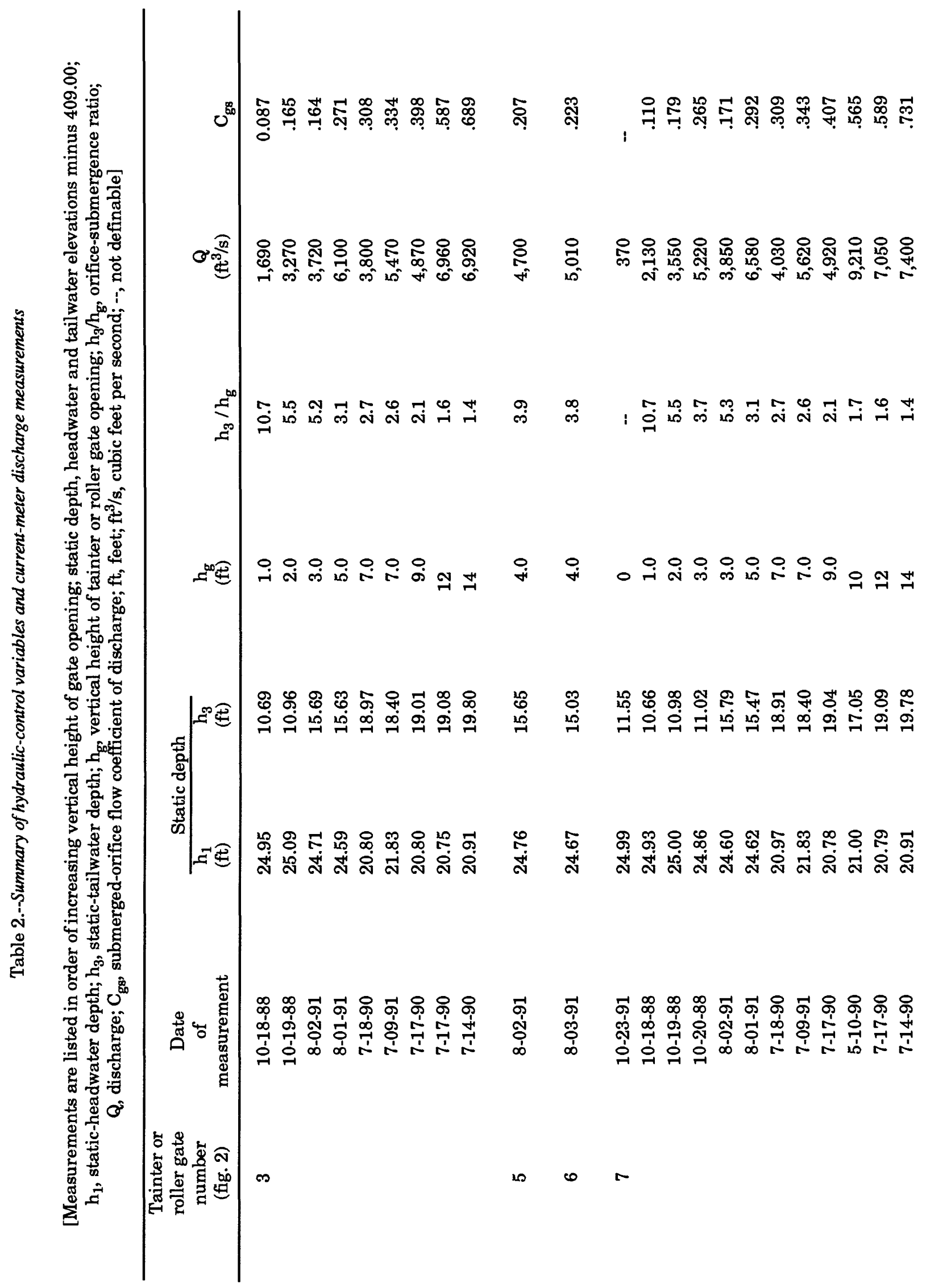




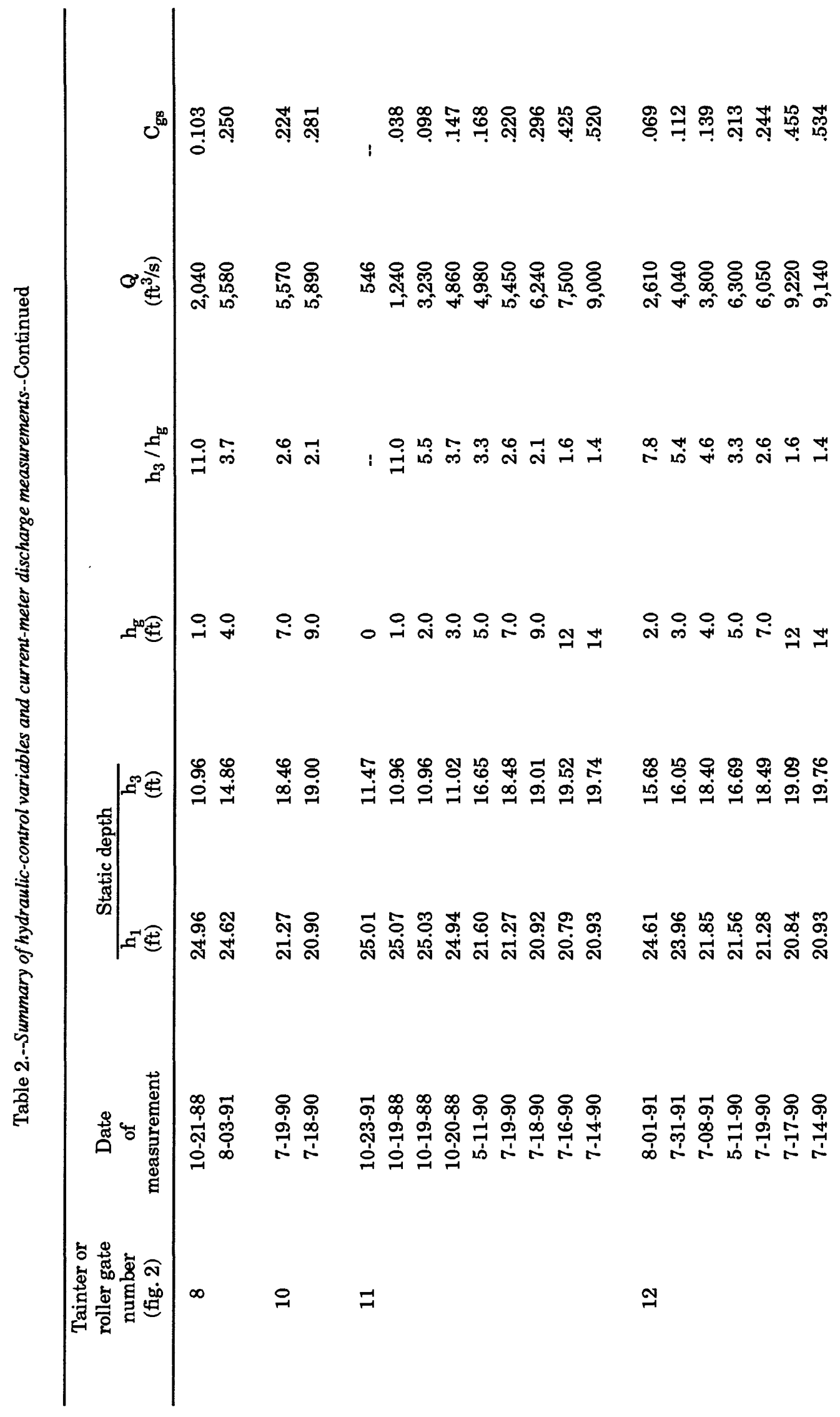




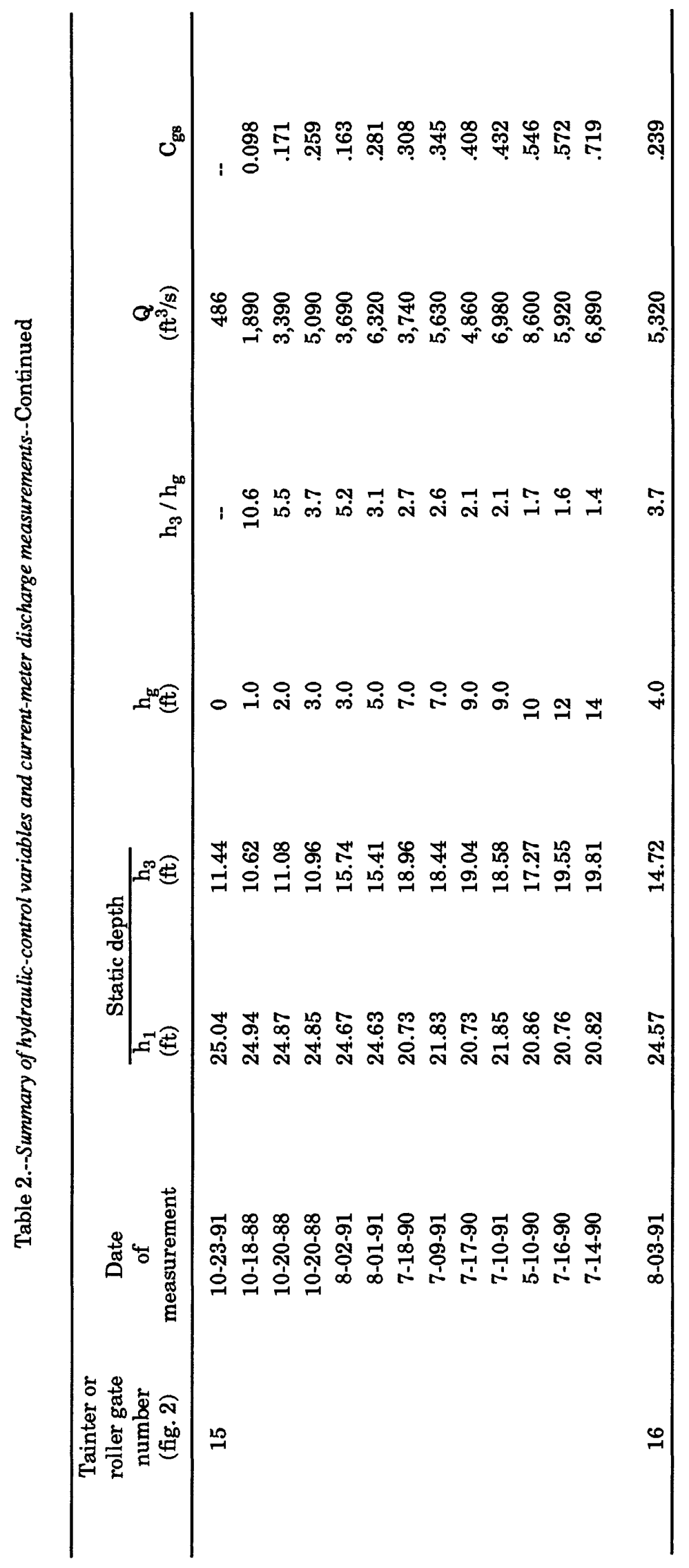




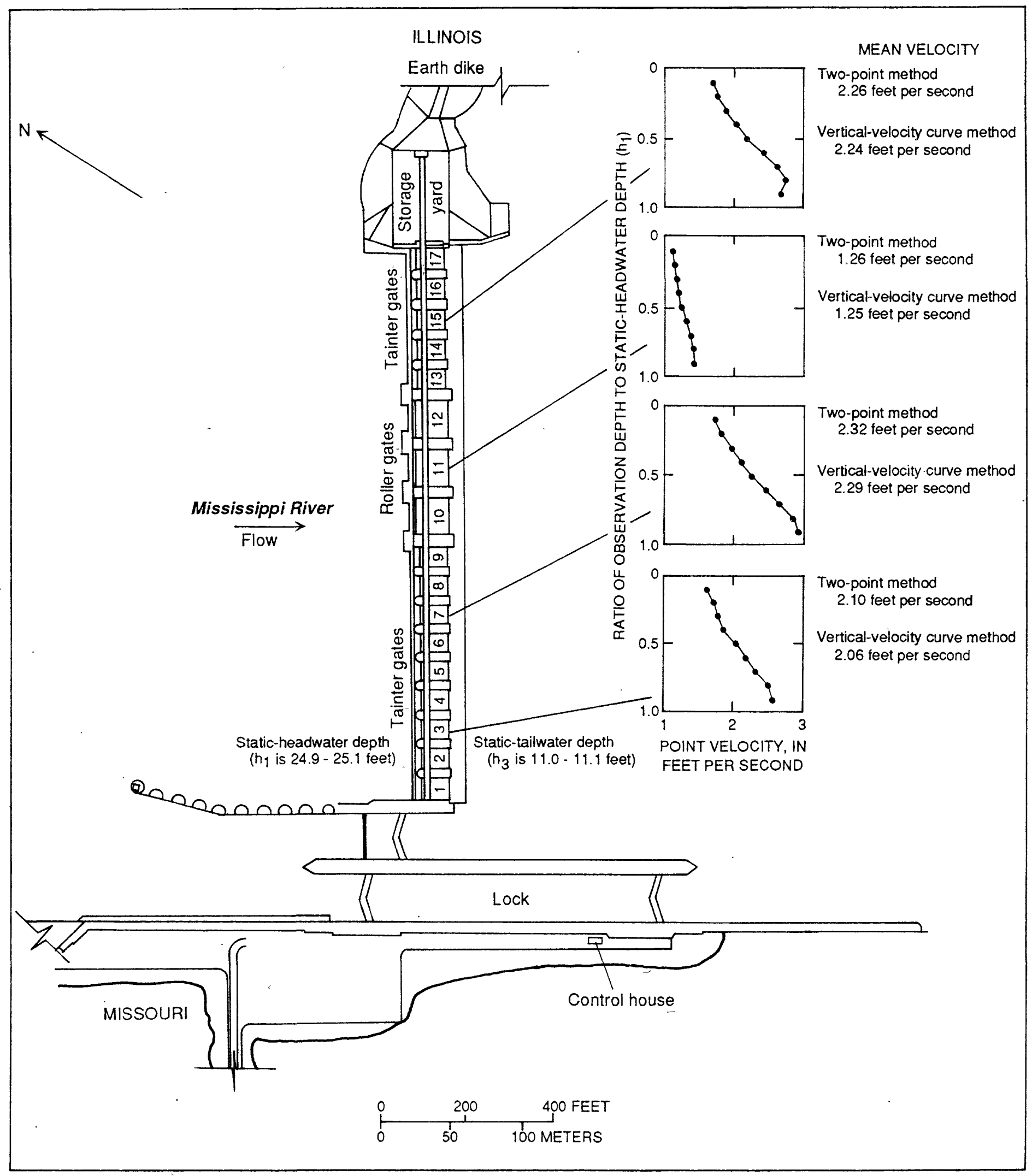

Figure 4.--Velocity observations of October 19-20, 1988, for a 2-foot gate opening at tainter gates $3,7,15$, and roller gate 11 . 


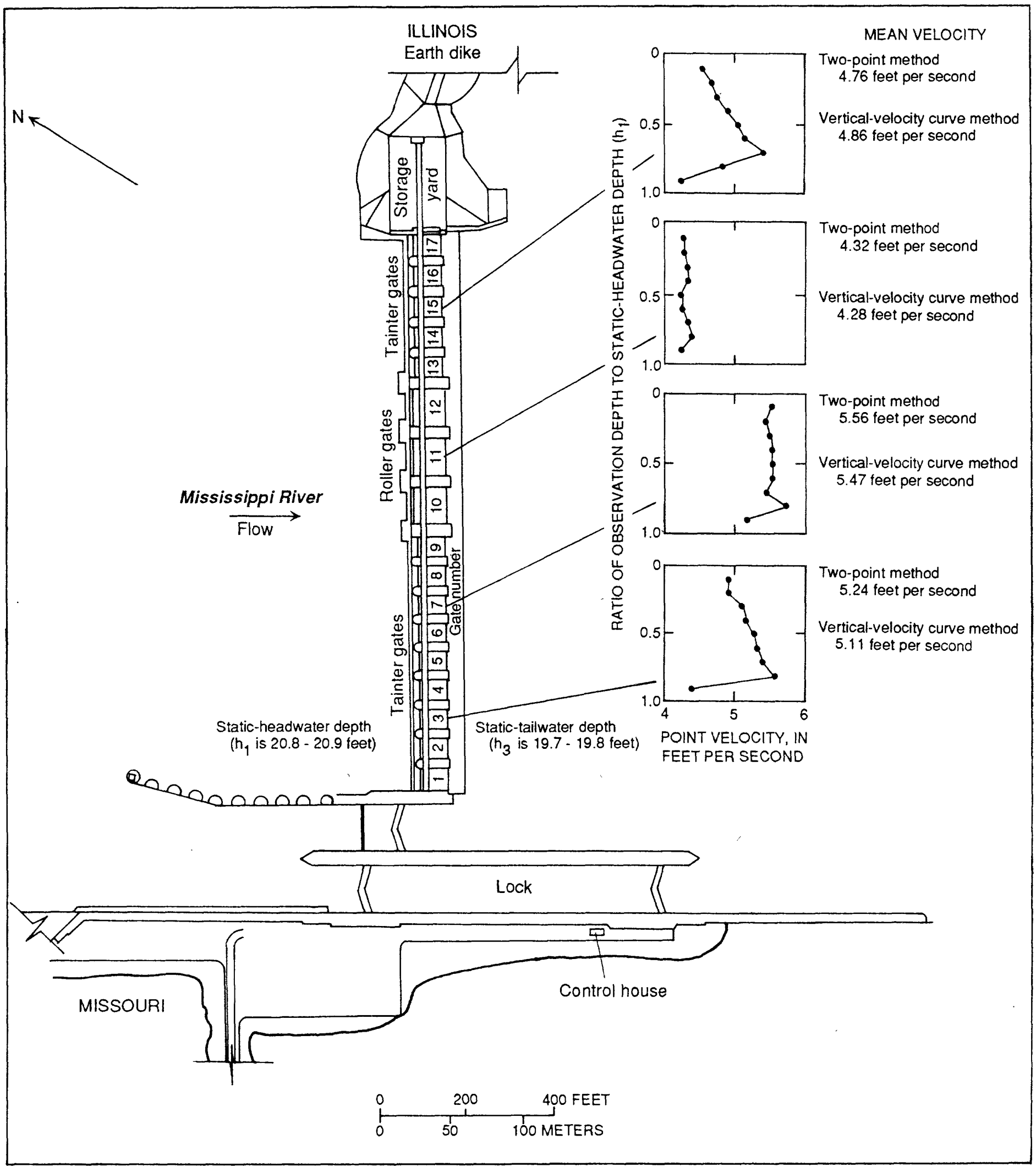

Figure 5.--Velocity observations of July 14,1990 , for a 14 -foot gate opening at tainter gates $3,7,15$, and roller gate 11 . 


\section{Tainter Gate Submerged-Orifice Discharge Coefficients}

Thirty-seven coefficients of discharge, $\mathrm{C}_{\mathrm{gg}}$, were computed (eq. 2) by using the results of the current-meter discharge measurements made at hydraulic-control conditions that satisfy the submerged-orifice flow criteria. The computed coefficients ranged from $0.087\left(h_{g}=1\right)$ to $0.731\left(h_{g}=14\right)$ and are listed in table 2 . The coefficient of discharge $\left(C_{g s}\right)$ and orifice-submergence ratio $\left(h_{3} / h_{g}\right)$ relation was graphically determined and is represented by the straight-line logarithmic relation shown in figure 6. As indicated by Collins (1977, p. 12), a break in this relation did occur when the orifice-submergence ratios were less than 2 . The discharge coefficient equation for orifice-submergence ratios from 2.0 to 11.0 is

$$
\mathrm{C}_{\mathrm{gs}}=0.820\left(\frac{\mathrm{h}_{3}}{\mathrm{~h}_{\mathrm{g}}}\right)^{-0.948} \text {. }
$$

For orifice-submergence ratios of 1.4 to 2.0 the equation is

$$
\mathrm{C}_{\mathrm{gs}}=1.15\left(\frac{\mathrm{h}_{3}}{\mathrm{~h}_{\mathrm{g}}}\right)^{-1.44} \text {. }
$$

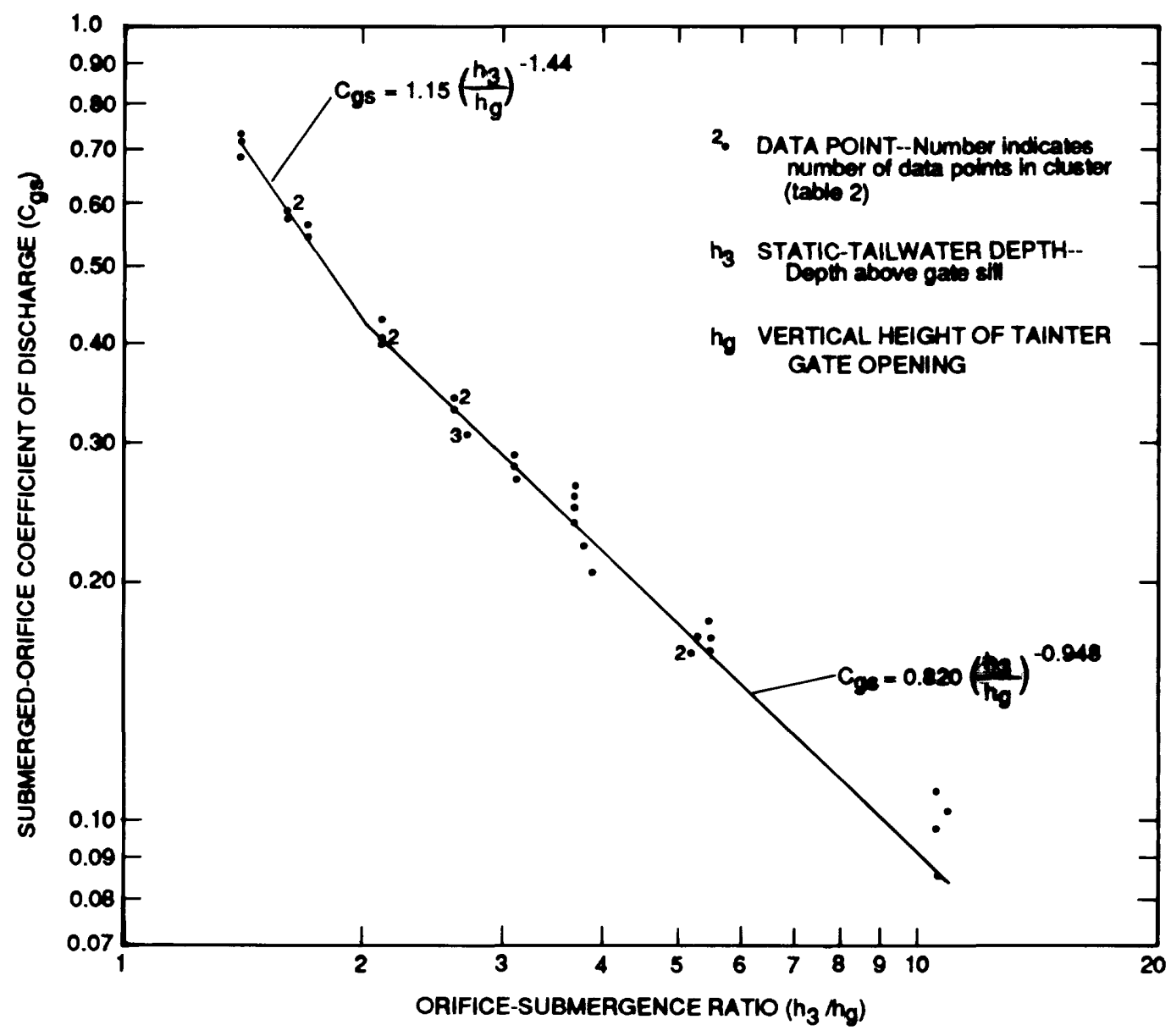

Figure 6.--Relation between submerged-orifice discharge coefficients and orifice-submergence ratios for tainter gates. 
Two current-meter discharge measurements made at $h_{g}=0$ (gates 7 and 15; table 2) indicate that leakage discharge per gate is about $420 \mathrm{ft}^{3} / \mathrm{s}$. This leakage discharge results because the lower seal of each tainter gate is worn or dented and does not form a tight fit against the concrete sill. The gate leakage discharge did affect the four coefficients of discharge computed for orifice-submergence ratios greater than $10.5\left(h_{\mathrm{g}}=1\right)$, as shown in figure 6 . Three of the four coefficients of discharge are greater than those extrapolated from figure 6; consequently, a current (1992) adjustment for leakage discharge per tainter gate $\left(\mathrm{q}_{\mathrm{GL}}\right)$ is developed in the next section.

\section{Tainter Gate Submerged-Orifice Discharge Equations}

An equation for computing submerged-orifice flow under a single tainter gate at Lock and Dam No. 25 was developed for orifice-submergence ratios from 2.0 to 11.0 by using the theoretical submerged-orifice equation of discharge (eq. 2) and substituting equation 5 for the discharge coefficient, $\mathrm{C}_{\mathrm{gs}}$. The resulting equation that relates discharge per tainter gate (Q) to the hydraulic-control variables of static-tailwater depth $\left(h_{3}\right)$, orifice-submergence ratio $\left(h_{3} / h_{g}\right)$, and static head differential $\left(h_{1}-h_{3}\right)$ is

$$
Q=395 h_{3}\left(\frac{h_{3}}{h_{g}}\right)^{-0.948}\left(h_{1}-h_{3}\right)^{0.5}
$$

Under current (1992) conditions, the two discharge measurements made at $h_{g}=0$ indicate that an average linear leakage discharge adjustment ( $\left.\mathrm{q}_{\mathrm{GL}}\right)$ of $0\left(\mathrm{~h}_{\mathrm{g}}=2\right)$ to $420 \mathrm{ft}^{3} / \mathrm{s}\left(\mathrm{h}_{\mathrm{g}}=0\right)$ per tainter gate is required to adjust for the difference between measured discharge (table 2 ) and the discharge calculated from equation 7. The adjusted equation then becomes

$$
Q=395 h_{3}\left(\frac{h_{3}}{h_{g}}\right)^{-0.948}\left(h_{1}-h_{3}\right) 0.5+q_{G L}
$$

however, the leakage discharge per gate $\left(\mathrm{q}_{\mathrm{GL}}\right)$ may require updating as worn gate seals are replaced or dented gate lips are repaired.

An equation for computing submerged-orifice flow under a single tainter gate was developed for orifice-submergence ratios from 1.4 to 2.0 by using equation 2 and substituting equation 6 for the discharge coefficient, $\mathrm{C}_{\mathrm{gs}}$. The resulting equation of discharge is

$$
Q=553 h_{3}\left(\frac{h_{3}}{h_{g}}\right)^{-1.44}\left(h_{1}-h_{3}\right)^{0.5} \text {. }
$$

\section{Roller Gate Submerged-Orifice Discharge Coefficients}

Seventeen coefficients of discharge, $\mathrm{C}_{\mathrm{gs}}$, were computed (eq. 2) by using the results of the current-meter discharge measurements made at hydraulic-control conditions that satisfy the submerged-orifice flow criteria. The computed coefficients ranged from $0.038\left(h_{g}=1\right)$ to $0.534\left(h_{g}=14\right)$ and are listed in table 2. The coefficient of discharge $\left(\mathrm{C}_{\mathrm{gg}}\right)$ and orifice-submergence ratio $\left(\mathrm{h}_{3} / \mathrm{h}_{\mathrm{g}}\right)$ relation was graphically determined and is represented by the straight-line logarithmic relation shown in figure 7. The discharge coefficient equation for a roller gate with orifice-submergence ratios from 1.4 to 11.0 is

$$
\mathrm{C}_{\mathrm{gs}}=0.790\left(\frac{\mathrm{h}_{3}}{\mathrm{~h}_{\mathrm{g}}}\right)^{-1.22}
$$




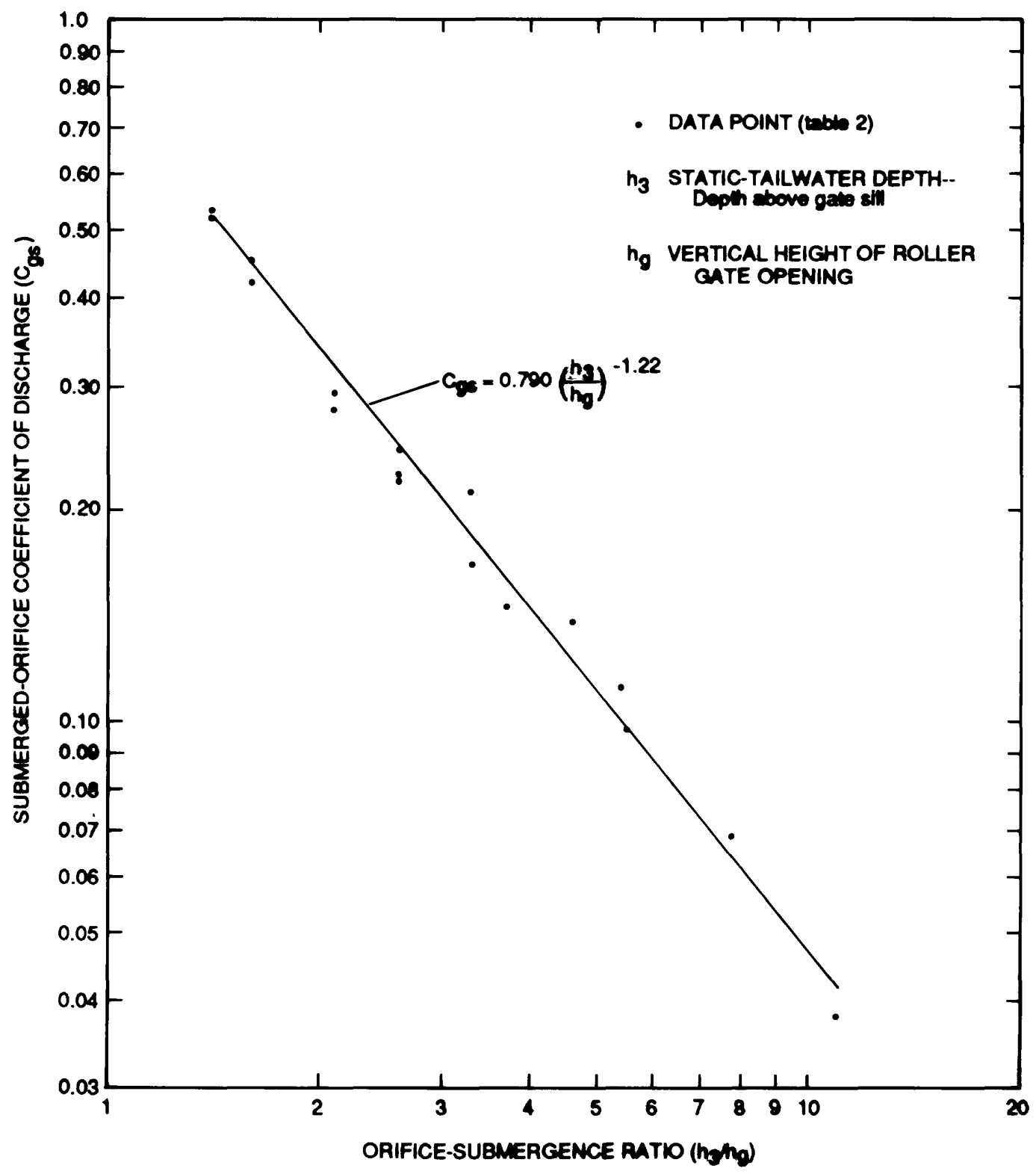

Figure 7.--Relation between submerged-orifice discharge coefficients and orifice-submergence ratios for roller gates.

The current-meter discharge measurement made at $h_{g}=0$ (gate 11; table 2) indicates that leakage discharge per gate is about $550 \mathrm{ft}^{3} / \mathrm{s}$. This leakage results because the lower seal of each roller gate is worn or dented and does not form a tight fit against the concrete sill. The leakage discharge did not seem to affect the discharge coefficient relation shown in figure 7; however, the current (1992) adjustment for leakage discharge per roller gate $\left(q_{G L}\right)$ is discussed in the next section. 


\section{Roller Gate Submerged-Orifice Discharge Equation}

An equation for computing submerged-orifice flow under a single roller gate at Lock and Dam No. 25 was developed for orifice-submergence ratios from 1.4 to 11.0 by using the theoretical submerged-orifice equation of discharge (eq. 2) and substituting equation 10 for the discharge coefficient, $\mathrm{C}_{\mathrm{gs}}$. The resulting equation that relates discharge per roller gate $(\mathrm{Q})$ to the hydraulic-control variables of static-tailwater depth $\left(h_{3}\right)$, orifice-submergence ratio $\left(h_{3} / h_{g}\right)$, and static head differential $\left(\mathrm{h}_{1}-\mathrm{h}_{3}\right)$ is

$$
\mathrm{Q}=633 \mathrm{~h}_{3}\left(\frac{\mathrm{h}_{3}}{\mathrm{~h}_{\mathrm{g}}}\right)^{-1.22}\left(\mathrm{~h}_{1}-\mathrm{h}_{3}\right) \text { 0.5 }
$$

Under current (1992) conditions, the discharge measurement made at $h_{g}=0$ indicates that an average linear leakage discharge adjustment $\left(\mathrm{q}_{\mathrm{GL}}\right)$ of $0\left(\mathrm{~h}_{\mathrm{g}}=1\right)$ to $550 \mathrm{ft}^{3} / \mathrm{s}\left(\mathrm{h}_{\mathrm{g}}=0\right)$ per roller gate is required to adjust for the difference between measured discharge and the discharge calculated from equation 11. When roller gate openings are equal to or greater than $1 \mathrm{ft}\left(\mathrm{h}_{\mathrm{g}} \geq 1\right)$, no leakage discharge adjustment is needed for the current (1992) roller gate lip or seal conditions.

\section{DISCHARGE RATINGS FOR TAINTER AND ROLLER GATES}

The discharge equations applicable to submerged-orifice flow under each tainter and roller gate at Lock and Dam No. 25 are summarized in table 3.

Table 3.--Summary of theoretical discharge equations for submerged-orifice flow under a single tainter or roller gate

$\left[\leq\right.$, less than or equal to; $h_{3}$, static-tailwater depth; $h_{g}$, vertical height of tainter or roller gate opening; $Q$, discharge per gate; $h_{1}$, static-headwater depth; $q_{G L}$, leakage discharge per gate; $\mathrm{ft}$, feet; $\mathrm{ft}^{3} / \mathrm{s}$, cubic feet per second]

\begin{tabular}{lccc}
\hline Flow control & $\begin{array}{c}\text { Hydraulic-control } \\
\text { conditions }\end{array}$ & Equation of discharge & $\begin{array}{c}\text { Equation } \\
\text { number }\end{array}$ \\
\hline Tainter gate & $2.0 \leq \frac{\mathrm{h}_{3}}{\mathrm{~h}_{\mathrm{g}}} \leq 11.0$ & $\mathrm{Q}=395 \mathrm{~h}_{3}\left(\frac{\mathrm{h}_{3}}{\mathrm{~h}_{\mathrm{g}}}\right)^{-0.948}\left(\mathrm{~h}_{1}-\mathrm{h}_{3}\right)^{0.5}+\mathrm{q}_{\mathrm{GL}}$ & 8 \\
Tainter gate & $1.4 \leq \frac{\mathrm{h}_{3}}{\mathrm{~h}_{\mathrm{g}}} \leq 2.0$ & $\mathrm{Q}=553 \mathrm{~h}_{3}\left(\frac{\mathrm{h}_{3}}{\mathrm{~h}_{\mathrm{g}}}\right)^{-1.44}\left(\mathrm{~h}_{1}-\mathrm{h}_{3}\right)^{0.5}$ & 9 \\
Roller gate & $1.4 \leq \frac{\mathrm{h}_{3}}{\mathrm{~h}_{\mathrm{g}}} \leq 11.0$ & $\mathrm{Q}=633 \mathrm{~h}_{3}\left(\frac{\mathrm{h}_{3}}{\mathrm{~h}_{\mathrm{g}}}\right)^{-1.22}\left(\mathrm{~h}_{1}-\mathrm{h}_{3}\right)^{0.5}$ & 11
\end{tabular}

Note: $q_{G L}$ is a linear adjustment per tainter gate of $0\left(\mathrm{~h}_{\mathrm{g}}=2 \mathrm{ft}\right)$ to $420 \mathrm{ft}^{3} / \mathrm{s}\left(\mathrm{h}_{\mathrm{g}}=0 \mathrm{ft}\right)$.

Discharge rating tables for normal headwater and tailwater elevations were developed from equations 8,9 , and 11 for submerged-orifice flow under a single tainter gate (table 4) and a single roller gate (table 5) with orifice-submergence ratios from 1.4 to $11.0\left(1 \leq \mathrm{h}_{\mathrm{g}} \leq 14\right)$. The discharge through Dam No. 25 for any combination of headwater-tailwater elevations, during normal submerged-orifice operating conditions, can readily be computed with a small programmable calculator by using the equations of discharge given in table 3. 


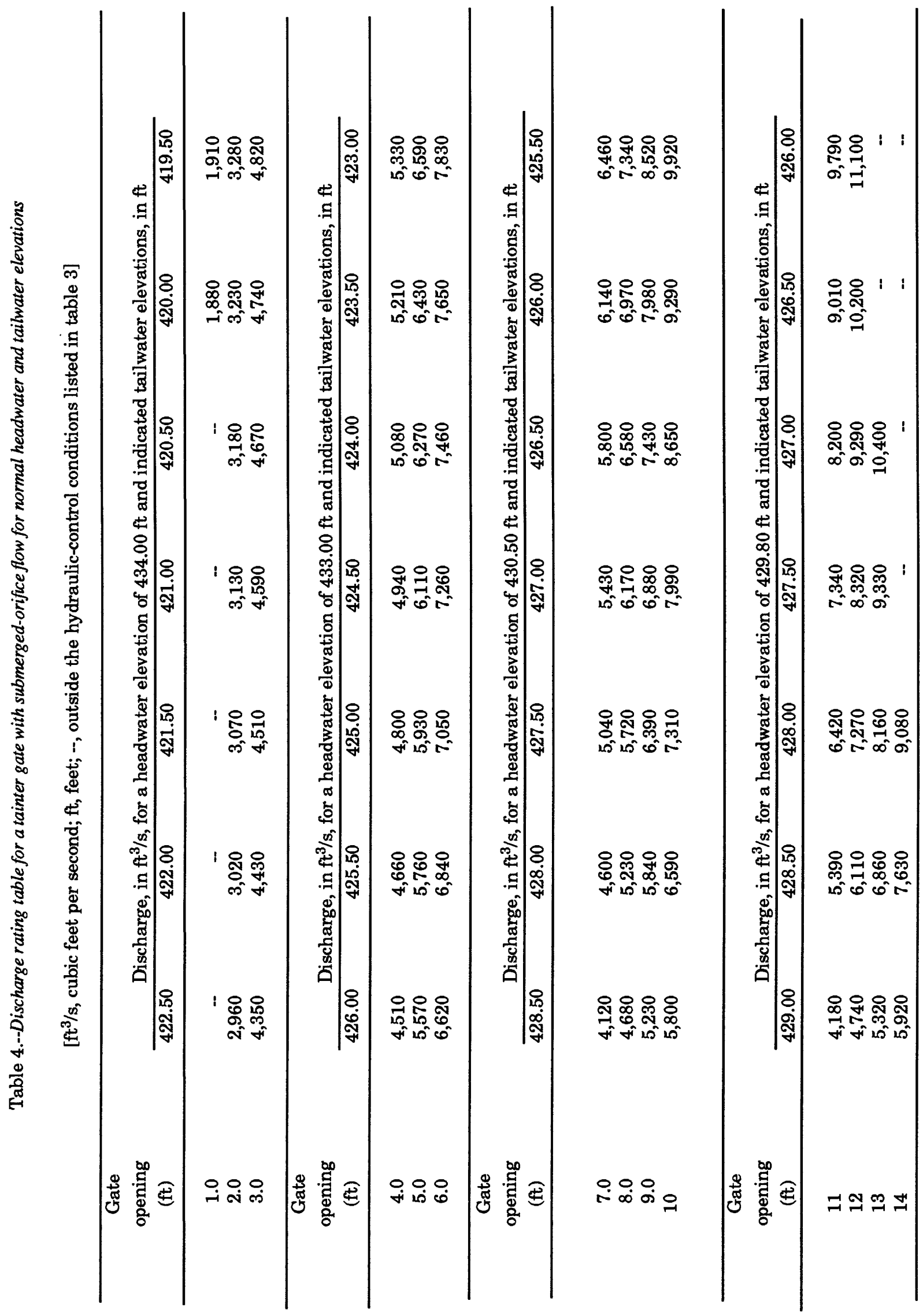




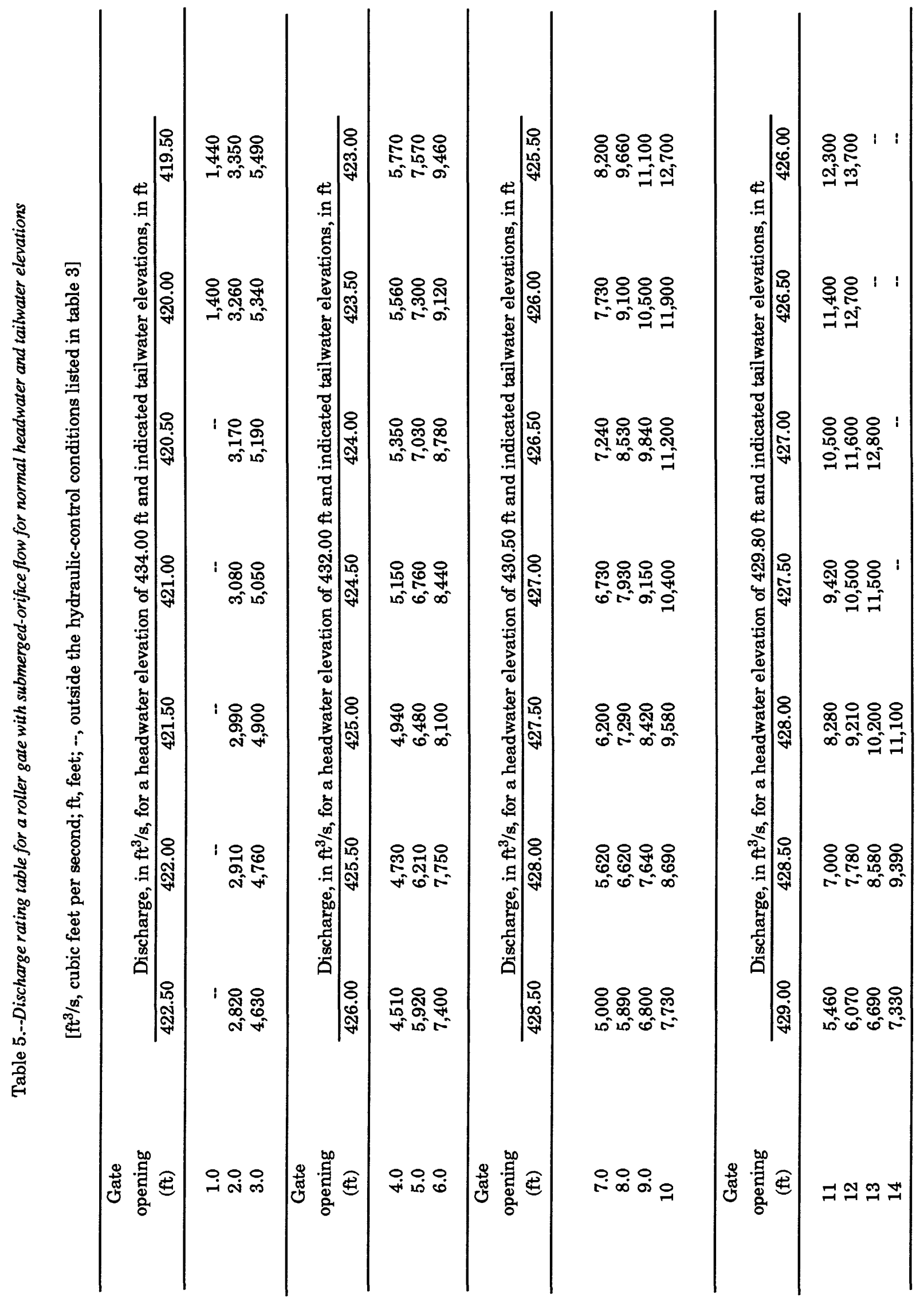




\section{SUMMARY}

Lock and Dam No. 25 includes 14 tainter and 3 roller gates that are regulated to control the water-surface elevation of the navigation pool and discharge of the Mississippi River near Winfield, Missouri. Stage-discharge relations for these tainter and roller gates during normal operating conditions have been developed and are presented here. These relations can be used by the U.S. Army Corps of Engineers (St. Louis District) in their water-control management of the upper Mississippi River basin. During high flow, all gates are raised out of the water to allow open-river flow. This unregulated condition was not evaluated in this study.

Fifty-seven current-meter measurements of discharges that ranged from 370 to 9,220 cubic feet per second were made in the forebays of selected tainter and roller gates. A total of 37 coefficients of discharge $\left(\mathrm{C}_{\mathrm{gs}}\right)$ ranging from $0.087\left(\mathrm{~h}_{\mathrm{g}}=1\right.$ foot) to $0.731\left(\mathrm{~h}_{\mathrm{g}}=14\right.$ feet) were used to define the submerged-orifice discharge coefficient relation for the 14 tainter gates. Also, 17 coefficients of discharge ranging from $0.038\left(\mathrm{~h}_{\mathrm{g}}=1\right.$ foot) to $0.534\left(\mathrm{~h}_{\mathrm{g}}=14\right.$ feet) were used to develop the discharge coefficient relation for submerged-orifice flow under the 3 roller gates. Submerged-orifice flow was the predominant flow regime at Lock and Dam No. 25. Three discharge measurements were made with the gates closed $\left(h_{g}=0\right)$ to evaluate the tainter and roller gate leakage discharge relations resulting from worn gate seals or dented gate lips that do not form a tight fit against the sill. A linear leakage discharge adjustment ( $\mathrm{q}_{\mathrm{GL}}$ ) of 0 cubic foot per second $\left(\mathrm{h}_{\mathrm{g}}=2\right.$ feet) to 420 cubic feet per second $\left(\mathrm{h}_{\mathrm{g}}=0\right.$ ) is needed under current (1992) conditions for each tainter gate; however, no leakage discharge adjustment is needed for roller gates at openings of 1 foot to 14 feet.

From these relations, the equations of discharge (two for tainter gates and one for roller gates) were developed that express discharge per gate $(\mathrm{Q})$ as a function of the discrete hydraulic-control variables of static-headwater depth $\left(h_{1}\right)$, static-tailwater depth $\left(h_{3}\right)$, and vertical height of gate opening $\left(h_{g}\right)$. These equations are applicable to tainter or roller gate openings of 1 foot to 14 feet with orifice-submergence ratios $\left(h_{3} / h_{g}\right)$ ranging from 1.4 to 11.0. The three equations of discharge are presented so that a tainter or roller gate elevation-discharge rating can be computed for any discrete combination of headwater-tailwater elevations not summarized in this report. Discharge rating tables for submerged-orifice flow under a single tainter gate and a single roller gate are given for navigation pool (headwater) elevations within Lock and Dam No. 25 normal operating limits of 429.70 to 434.00 feet and selected tailwater elevations. 


\section{REFERENCES CITED}

Collins, D.L., 1977, Computation of records of streamflow at control structures: U.S. Geological Survey Water-Resources Investigations $77-8,57 \mathrm{p}$.

Rantz, S.E., and others, 1982, Measurement and computation of streamflow--Volume 1. Measurement of stage and discharge: U.S. Geological Survey Water-Supply Paper 2175, 284 p.

Stuthmann, N.G., and Sanders, Jr., C.L., 1982, Instructions for processing digital streamflow data collected at dams (program E466), in Watstore user's guide: U.S. Geological Survey Open-File Report 77-729, v. 5, Chap. II, 45 p.

U.S. Army Corps of Engineers, 1980, Project maps: St. Louis, U.S. Army Engineer District, 175 p. 